\title{
Muslims in the Western Imagination
}

\author{
Sophia Rose Arjana \\ New York: Oxford University Press, 2015. 261 pages.
}

Through research spanning 1,300 years, Sophia Rose Arjana presents a historical genealogy of monstrous representations of Muslims that haunt the western imagination and continue to sustain the contemporary bigotry of Islamophobia. The central question introduced in the first section, "Introduction: Islam in the Western Imagination," is "How did we get here, to this place of hijab bans and outlawed minarets, secret renditions of enemy combatants, Abu Ghraib, and GTMO?" (p. 1).

To answer this question, Arjana highlights connections between historical representations of Muslims and monstrosity in imagery, literature, film, and popular culture to produce a volume she describes as "an archive of Muslim monsters" and "a jihad - an effort - to reveal Muslims as human beings instead of the phantasms they are often presented as" (p. 16). This work is a timely contribution that will benefit scholars researching anti-Muslim sentiment, Islamophobia, postcolonial and subaltern studies, the psychology of xenophobia and genocide, or who are interested in historical manifestations of Islamophobia, antisemitism, and racism in art, literature, film, and media.

In the first chapter, "The Muslim Monster," the author argues that cultural "ideas of normativity are often situated in notions of alterity" and that monstrous representations of Muslims have functioned as an enduring signifier of alterity against which the West has attempted to define itself since the Middle Ages. Through the production of dehumanized and monstrous representations, Muslims became part of a mythological landscape at the peripheries of Christian civilization that included dragons, giants, and dogheaded men. The grotesque and uncanny attributes of monsters reveal the anxieties of the society that produces such images, and chief among those is the fear of racial contamination and the dissolution of culture through intermingling with the foreign and the strange. Each of the following chapters focuses on depictions of Muslims as monsters in visual arts and literature within a particular era or context.

The second chapter, "Medieval Muslim Monsters," introduces Muslim monsters of the Middle Ages, many of which survived as tropes used to vilify Muslims, Arabs, Jews, and Africans for centuries thereafter. This chapter introduces monsters such as "the giant, man-eating Saracens of medieval romances and the Black Saracens, often shown in medieval art executing saints, harassing and killing Jesus, and murdering other Christian innocents" (p. 19) 
and Muslims "portrayed as demons, black-skinned monsters, Satan, or souls condemned to the underworld" (p. 25). Arjana describes the imagination of a monster geography in which sinister creatures dwell in dark and unnatural lands, always threatening to transgress into Christian space.

A parallel to this is the casting of Prophet Muhammad in terms of perversion, by identifying him as a heretic, schismatic, or sexual deviant whose appetites and teachings transgressed the boundaries established by God, decency, and the Church. Such representations demonstrate the special place of Muslims as catch-all miscreants possessing every negative trait and against which medieval Christian identity could be defined as pure and good.

The third chapter, "Turkish Monsters," reveals European Christian insecurities following the Ottoman conquest of Constantinople. As a powerful Muslim empire that had overtaken a former hub of Christendom, the Ottomans exemplified a threatening alterity. Consequently, turbans and other recognizably Ottoman symbols evoked not only Muslims, but also Jews, as being quintessentially non-European. Examples provided in this chapter include paintings of turbaned figures attending the dismemberment of Christian martyrs, Elizabethan dramas such as Marlowe's Tamburlaine and Shakespeare's Othello that include anti-Muslim themes, and the icon known as a Turk's head, which was used in Elizabethan cooking and sport. Fantastic stories about Muslims and their bleak, haunted lands became common elements in the literature of the era until Muslims were very nearly naturalized within the realm of myth in the same terms as dragons, giants, and demons.

Chapter 4, "The Monsters of Orientalism," describes the place Muslims came to occupy in the fantasy stories of early modernity and within the literary genres of the Enlightenment, Orientalism, Romanticism, and Gothic horror. Islam was utilized in allusive critiques of Catholicism and religion in general as being superstitious and irrational, and served as a marker of the fantastic and sensual in travelers' accounts of exotic lands. In Orientalist works, it became the symbol par excellence of the mysterious East against which the West and western identity must be distinguished and defined. Within the context of colonialism, Muslims and Jews were racialized as Orientals, essentially backward and irrational people who could never assimilate into modern western societies.

As racialized characters in literature, they represented anxiety about the racial purity of Europeans. Arjana describes the colonization of the Orient and the corresponding commodification of Oriental tropes into cultural products, including their use in the literature of Romanticism and Gothic horror, where villains in stories such as Vathek, Zafloya, and Dracula were made more mon- 
strous by possessing an Oriental mystique. In these genres, mere association with Islam or the East enhances a character's monstrosity and evil.

In chapter 5, "Muslim Monsters in the Americas," she charts the development of medieval representations of Muslim monsters in the context of New World exploration. Muslim monster archetypes contributed to the imagination of a Christian American destiny and the divine inheritance of a new Promised Land. In the process, "explorers constructed a complex narrative about the people they encountered. This included claims that they were devilworshipers, as if American Indians were lapsed Christians. American Indians were also identified with Muslims" (p. 138), or with Moors or Moriscos.

In this chapter, Arjana also introduces the construction of Muslim monsters in Hollywood films and in television series, in which "Muslim characters are depicted as villains harassing, kidnapping, raping, terrorizing, and killing innocents, often Americans or Europeans," and notes that "Muslim men have been depicted as medieval and have been juxtaposed with white Christian moderns" (p. 141) with a striking regularity. The popularity of films featuring Muslim or Arab villains formed a standard model for plots in which Muslim men play the parts of cruel, violent, and sexually aggressive villains who pose a threat to the safety and purity of white Christian women. At the same time, the contrast between the white hero and the savage Oriental villain are used to create a new sense of time in which modernity and civilization are uniquely western, while Muslims are imagined as inhuman relics of a barbaric past.

In the second half of chapter 5 and in chapter 6, "The Monsters of September 11," Arjana describes monsters imagined in the "war on terror" and post-9/11 America, including the reduction of real-life terrorists to caricatures driven by hatred and conceived as mere "killing machines whose lives hold no value" (p. 151). In the same period, movies about alien invasions or zombie hoards provided an outlet for anxieties about terrorist sleeper cells whose brutal ideology might infect the minds of Americans and transform them, zombielike, into killing machines.

The author describes the news media's adoption of phrases and tropes from fantasy films when describing Muslims, as well as the proliferation of monster movies mirroring shifts in the political discourse about Muslims. The frightening result of Muslims being so closely linked with fantasy monsters has been the perpetration of indiscriminate violence against real Muslim bodies paralleling the violence against zombies or other monsters in horror films. Linking dehumanization with violence, Arjana describes crimes committed in the context of the twentieth century's wars, genocides, and at Abu Ghraib, where atrocities committed by American soldiers were revealed through leaked images, 
such as those of "the hooded figure connected to electrical wires, the naked man on a dog leash held by a female soldier who smiles for the camera, the naked piles of bodies, and the other bodies, some alive, some dead ... soldiers grinning for the camera, giving the thumbs up" (pp. 178-79), and so on.

Arjana begins this book by stating that "the portrayal of Muslims as the antithesis of good Americans is not only common - it is the norm" (p. 10), and ends by warning that "the post-human condition of Muslims is something that has yet to be undone" (p. 183). The inhuman treatment of Muslim detainees in Abu Ghraib and elsewhere, as well as the persistence of anti-Muslim rhetoric and Islamophobia worldwide, stand as grim evidence supporting her argument.

Some of the monsters in this work, such as the dog-headed cynocephalie referenced in every chapter except the last, may seem to be only tenuously linked with hijab bans, GTMO, or the general vilification of Muslims. However, the persistence of this image speaks to its power as a symbol of Oriental alterity. Certainly, all of the examples in this collection support Arjana's compelling argument that imagery and representations disfiguring the inward or outward humanity of a group re-imagines that group within the class of monsters. This serves the political function of distinguishing us from them and seeks to excuse or justify the vilification, abuse, or extermination of the Other. Through her genealogy of Muslim monsters, Arjana has revealed the discursive process by which humans are imagined as monsters so that monstrous violence can be perpetrated against them with the pretense of legitimacy.

Brendan Newlon

Doctoral Candidate, Department of Religious Studies University of California, Santa Barbara, CA 